(C2007 IEEE. Personal use of this material is permitted. However, permission to reprint/republish this material for advertising or promotional purposes or for creating new collective works for resale or redistribution to servers or lists, or to reuse any copyrighted component of this work in other works must be obtained from the IEEE. 


\title{
Impact of Harmonics on Tripping Time of Overcurrent Relays
}

\author{
M.A.S. Masoum, SM IEEE, S.M. Islam, SM IEEE, K. Tan, $M$ IEEE, N.X. TUNG
}

\begin{abstract}
Theoretical and experimental analyses are used to investigate the effects of harmonics on the operation of overcurrent relays. Two analytical approaches based on relay characteristics provided by the manufacturer and simulations using PSCAD software package are used to estimate tripping times under non-sinusoidal operating conditions. The tests were conducted such that the order and the magnitude of harmonics could be controlled by employing a computer-based single-phase harmonic source. Computed and measured tripping times are compared and suggestions on the application of overcurrent relays in harmonically polluted environments are provided.
\end{abstract}

Index Terms-- Overcurrent relay, harmonic, tripping time and power quality.

\section{INTRODUCTION}

$\mathrm{D}$ ue to the extensive application of nonlinear loads and the introduction of renewable energy devices the load current usually contains harmonic components that affect the operating characteristic of the overcurrent relay. The technical literature is filled with documents and references to harmonics in power systems [1-9], however, few have addressed the influence of these waveform distortions on protective relays [10-13].

Power system problems associated with harmonics are not new to utility and industrial systems. Waveform distortions and harmonic injections are caused by nonlinear loads and electromagnetic devices. Electrical loads in industrial, commercial, and residential sectors of power system are typically a combination of linear and nonlinear loads. Any device with a nonlinear characteristic may be responsible for injecting harmonic currents and voltages into the electrical system. With the advancement of solid-state switching technology and higher energy efficiency achieved from powerelectronic driven loads, the numbers of nonlinear loads are rapidly increasing. Examples of linear loads are incandescent lamps, motors, heaters, conventional ovens, and air conditioning; whereas nonlinear/power-electronic loads include fluorescent lamps, adjustable-speed drives, converters, computers, and other electronic home appliances, such as television sets, video players, etc.

Mohammad A.S. Masoum, Syed Islam and Kelvin Tan are with Department of Electrical Engineering, Curtin University of Technology, Perth, WA6845, Australia (email: m.masoum@curtin.edu.au).

Nguyen Xuan Tung is with Department of Electrical Engineering, Shibaura Institute of Technology, Tokyo, Japan (email: nx_tung-htd@mail.hut.edu.vn).
Other sources of harmonics in power system are arc furnaces, saturated transformers, arcing faults, thyristor switching loads, transformer energization and capacitor bank switching. While nonlinear loads are considered as sources of harmonics, linear loads act as damping elements to harmonic propagation and affect the resonance frequency of the distribution system.

The effects of non-sinusoidal voltages and currents on the performance of underfrequency and overcurrent relays were experimentally studied by Fuller, Fuchs et al. [10]. It was found that for harmonic voltage and current amplitudes, underfrequency relays and the time delay operation of overcurrent relays show a marked deterioration in their performance; however, the instantaneous operating characteristics of overcurrent relays are hardly affected.

Girgis,et al. [11] studied the effects of voltage and current harmonics on the operation of four types of solid-state relays (SSR's). Their experimental results indicate that voltage harmonic distortion may cause a delay in the turn-on time of more than a cycle. In some cases, complete failure to turn on or off may occur. Reference [12] addresses the effect of harmonics on the operation of directional distance (OHM unit) relay. Their experimental results show that the relay will report a wrong fault location in the presence of the harmonic distortion. The relay is frequency sensitive up to $20 \mathrm{kHz}$, the highest testing frequency, and it is a phase sensitive when voltage and current are distorted. A number of relays were tested and each responded differently to harmonic distortions. Elmore, et al. [13] describe the theoretical expectations of harmonic influence and present laboratory confirmation of the results. The results indicate that the influence of mixed frequency harmonics (with magnitude decreasing with order) on the steady state behavior of the protective relays studied is minor and insignificant; however, a distinct change in relay operation is reported for single harmonic injections.

In this paper, two analytical approaches based on relay characteristics provided by the manufacturer and simulations using PSCAD software package are used to investigate the performance of overcurrent relays under non-sinusoidal operating conditions. Tripping times are computed and compared with measurements for current waveform distortions containing low order harmonics with different THD levels. Theoretical and experimental analyses of this paper indicate that waveform distortion of load current will alter tripping time of overcurrent relays. Suggestions on the application of relays in harmonically polluted environments are provided. 


\section{TRIPPING TIME FROM RELAY CHARACTERISTICS}

\section{A. RMS and THD of the Non-Sinusoidal Load Current}

It is imperative to size the overcurrent device to true rms as measured by a true rms meter. Average sensing, rms equivalent meters do not correctly respond to harmonic

- The fundamental component of the distorted load current is varied from 1.20 to 4.4 times of the pickup current.

current. Harmonic-rich currents will have higher effective rms as compared to non-distorted sinusoidal waveforms.

The rms value of a pure sinusoidal waveform $\left(\mathrm{I}_{\mathrm{rms}}=\mathrm{I}_{1 \mathrm{rms}}\right)$ is defined as:

$$
I_{1 \mathrm{rms}}=\sqrt{\frac{1}{2 \pi} \int_{0}^{2 \pi} I_{1 \max } 2 \sin ^{2}(\omega t) d t}=\frac{I_{1 \max }}{\sqrt{2}}
$$

The rms value of a non-sinusoidal current waveform ( $\left.\mathrm{I}_{\mathrm{ns}-\mathrm{rms}}\right)$ is defined as:

$$
\begin{aligned}
& I_{n s-r m s}^{2}=\frac{1}{2 \pi} \int_{0}^{2 \pi} i^{2}(t) d t=\frac{1}{2 \pi} \int_{0}^{2 \pi}\left[I_{1 \max } \sin \left(\omega t+{ }_{1}\right)+\right. \\
& \left.I_{2 \max } \sin \left(2 \omega t+{ }_{2}\right)+\ldots .+I_{n \max } \sin \left(n \omega t+{ }_{n}\right)\right]^{2} d t \\
& =\frac{I_{1 \max }^{2}}{2}+\frac{I_{2 \max }^{2}}{2}+\ldots . .+\frac{I_{n \max }^{2}}{2}
\end{aligned}
$$

Simplifying the above equation results in

$$
\mathrm{I}_{\mathrm{ns}-\mathrm{rms}}=\sqrt{\mathrm{I}_{1 \mathrm{rms}}^{2}+\mathrm{I}_{2 \mathrm{rms}}^{2}+\ldots+\mathrm{I}_{\mathrm{nrms}}^{2}}
$$

The total harmonic distortion of load current is defined as:

$$
\begin{aligned}
& \mathrm{THD}_{\mathrm{I}}=\frac{\mathrm{I}_{\mathrm{h}}}{\mathrm{I}_{1 \mathrm{rms}}} \times 100 \% \\
& \text { where } \mathrm{I}_{\mathrm{h}}=\sqrt{\mathrm{I}_{2 \mathrm{rms}}^{2}+\mathrm{I}_{3 \mathrm{rms}}^{2}+\ldots+\mathrm{I}_{\mathrm{nrms}}^{2}} .
\end{aligned}
$$

\section{B. The Standard Characteristic of Relay}

A solid state overcurrent relay type MCGG of Alstom T\&D Protection \& Control Ltd [14] is used. Operating time characteristics of the relay are provided by manufacturer as follow:

- Standard Inverse Characteristic (SI)

$$
\mathrm{t}_{\mathrm{si}}=\frac{0.14}{\left[\mathrm{I}^{0.02}-1\right]} \mathrm{sec}
$$

- $\quad$ Very Inverse Characteristic (VI)

$$
\mathrm{t}_{\mathrm{vi}}=\frac{13.5}{[\mathrm{I}-1]} \mathrm{sec}
$$

- $\quad$ Extremely Inverse Characteristic (EI)

$$
\mathrm{t}_{\mathrm{ei}}=\frac{80}{\left[\mathrm{I}^{2}-1\right]} \mathrm{sec}
$$

where $t_{\mathrm{si}}, \mathrm{t}_{\mathrm{vi}}$ and $\mathrm{t}_{\mathrm{ei}}$ are the tripping times based on the standard inverse, very inverse and extremely inverse characteristics, respectively, $\mathrm{I}=\mathrm{I}_{\text {input }} / \mathrm{I}_{\text {pickup }}$ and $\mathrm{I}_{\text {pickup }}$ is the relay current set point.

\section{Estimated Tripping Time from Standard Characteristics}

- To investigate the impact of waveform distortion on the tripping time of the relay (Eq. 4), a single-phase rectifier load current with the following harmonic spectrum is assumed:For $10 \%$ of Total Harmonic Distortion $\left(\mathrm{THD}_{\mathrm{I}}\right)$, amplitudes of fundamental, third, fifth and seventh harmonics current components are set to $100 \%, 9.03 \%, 3.92 \%$ and $3.04 \%$, respectively.

- For higher $\mathrm{THD}_{\mathrm{I}}$ levels (e.g., $20 \%$ and $30 \%$ ), the fundamental component of the load current is maintained while the magnitudes of harmonic distortions are proportionally increased.

- Three characteristic of relay are tested: Standard Inverse; Very Inverse and Extremely Inverse.

- Higher harmonic orders can be included, however, they are assumed to be negligible in this investigation.

Tripping times of the relay computed from the standard characteristics provided by the manufacturer (Eq.4) are computed and shown in Table 1 (rows $1,4,7,10,13,16,19$, $22,25)$ for three levels of THD load current $\left(\mathrm{THD}_{\mathrm{I}}=10 \%\right.$, $20 \%$ and $30 \%$ ).

\section{SOFTWARE SIMULATION}

For the simulation of the relay under non-sinusoidal operating conditions, Power Systems CAD (PSCAD) which is a powerful and flexible graphical user interface to the EMTDC solution engine is utilized [15]. This software package enables the user to schematically construct a circuit, run a simulation, analyze the results, and manage the data in a completely integrated graphical environment.

The simulation model is built based on current sources and overcurrent relays. PSCAD software library has a model for the Alstom overcurrent relay with pre-defined characteristics. Simulated vales of tripping times of the relay generated by PSCAD for current THD values of $10 \%, 20 \%$ and $30 \%$ are shown in Table 1 (rows 2, 5, 8, 11, 14, 17, 20, 23, 26).

\section{MEASUREMENTS}

A single-phase testing system for measuring the effects of (individual and/or mixed) harmonic currents on the performance and tripping time of protective relays has been developed (Figs. 1-2). A computer based waveform generator, an amplifier and corresponding software and interface circuits are used to test a solid state over-current relay of type MCGG manufactured by Alstom T\&D Protection \& Control Ltd. Individual harmonic currents and any combinations of up to four harmonic components with desired orders, magnitudes 
and phase shifts can be injected and the corresponding tripping times could be measured. Experiments are performed for:

- $\quad$ sinusoidal currents, and

- distorted currents with low order harmonics.

The results of first test are used to determine the standard characteristic of the relay as provided by the manufacturer. The second test is to determine the effect of harmonics on characteristic of relay and to measure the deviations of tripping times.

Figure 2 shows the measurement setup consisting of:

Waveform Generator- The computer based waveform generator uses software to generate non-sinusoidal signals with the desired harmonic magnitudes and harmonic phase angles. The signal is transferred through sound card of the computer.

Software Specifications and Features- DaqGen is the stimulus signal generator [16] that allows any Windowssupported sound card to become a continuous real-time signal generator. Unlike systems that simply play back a static buffer, DaqGen's continuous generation allows not only extremely fine frequency resolution, but also extremely long tone bursts and frequency sweeps (hours or days) and complex signal interactions. Two output channels are supported. These may be used together for stereo, or independently. The two outputs can be quickly swapped, or forced one output to sound alone (Solo), or send one channel to both outputs (Dual). Each channel can be a combination of up to 4 independent signal streams, each with its own set of control dialogs. Each stream has independent controls for Wave type, frequency, level, and combination of modulators. Alternatively, instead of going to the output, a stream can be used as a modulation source for other streams of the same output, allowing extremely complex modulation schemes.

Power Amplifier- Normally, the output signal of sound card is weak and not suitable for testing purposes. To amplify the signal to the desired level, a power amplifier was built which can generate a current up to 4A. A 20W Amplifier Module Kit (K5116) manufactured by Altronic Company, Australia is used. This amplifier is based on single IC, the LM1875T 20W audio amplifier from National Semiconductor. This IC can delivers over 20W RMS output with a signal to noise ratio of $105 \mathrm{~dB}$, distortion figure of less then $0.04 \%$ (for $1 \mathrm{kHz}$ at $20 \mathrm{~W}$ ) and a frequency response from $14 \mathrm{~Hz}$ to $100 \mathrm{kHz}$.

Resistor- A variable resistor of maximum $10 \Omega$ is used as the load to limit the output current of amplifier.

Relay- Experiments are performed for an Alstom single phase overcurrent relay type MCGG $\left(\mathrm{I}_{\mathrm{n}}=1 \mathrm{~A}, \mathrm{f}=50 \mathrm{~Hz}\right.$ and $\mathrm{Vx}=$ $110 \mathrm{~V})$. This relay uses solid state techniques, each measuring board utilizing a micro-computer as a basic circuit element. The current measurement, whether perform on a single phase or poly phase input, is performed via an analogue to digital converter. Main features of the relay are:

- Choice of 4 inverse time curves and 3 definite time ranges by switched selection.

- Wide setting range of $0.05 \mathrm{xI}_{\mathrm{n}}$ to $2.4 \mathrm{xI}_{\mathrm{n}}$ in step of $0.05 \mathrm{XI}_{\mathrm{n}}$.
- Time multiplier range from 0.05 to 1 on all seven characteristics.

- LED start indicators to facilitate testing.

- Output contact for time delay phase fault.

- Low AC burden.

- Accurately follows time curves to BS 142 and IEC60255

- High resetting ratio and fast resetting time.

- Separate setting switches for each measuring board to select the required time/current characteristic, current and time multiplier settings.

Digital Timer- This digital timer is a combination of a timer and an internal 3 phase contactor. When "START" button is pressed then timer starts counting and at same time contactor is closed. "STOP" button can be used to open contactor and stop timer. Resolution of timer is $10 \mathrm{~ms}$.

Power Quality Analyzer FLUKE 43- Power quality analyzer is mainly used to capture waveforms of injected current and measure total harmonic distortion $\left(\mathrm{THD}_{\mathrm{I}}\right)$.

Using the experimental set up of Figure 2; tripping times of the relay are measured for distorted currents with THD levels of $10 \%, 20 \%$ and $30 \%$, as specified in Section II. The fundamental component is varied from 1.20 to 4.4 times of the pickup current. Table 1 (rows 3, 6, 9, 12, 15, 18, 21, 24, 27) shows the measured tripping times for three different operating characteristics.

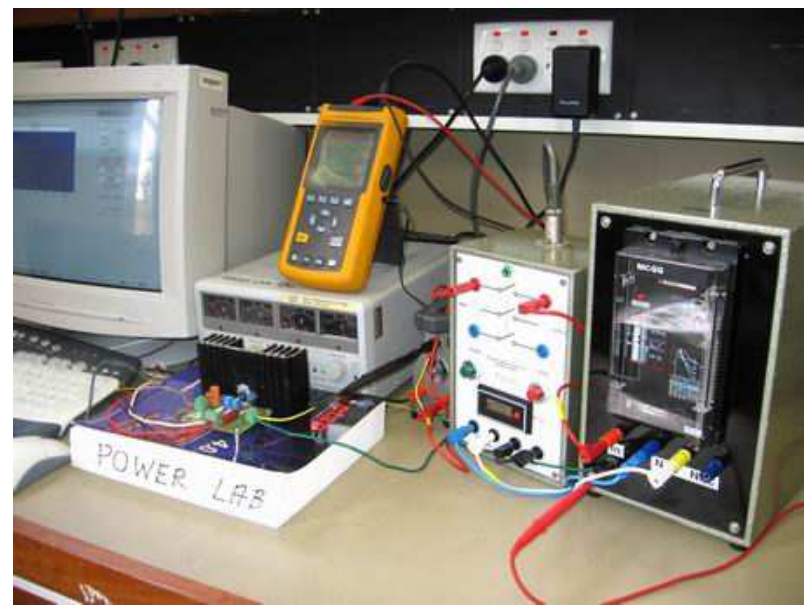

Fig. 1 Photograph of the testing bench 


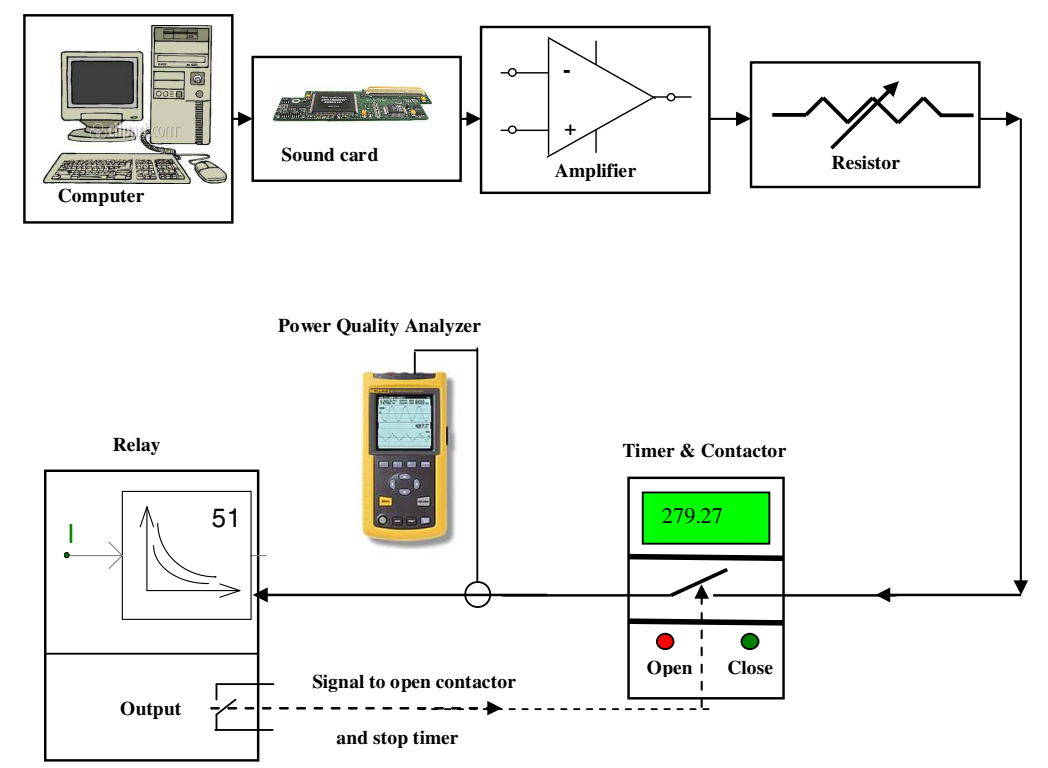

Fig. 2 Measurement of tripping time under non-sinusoidal operating conditions

TABLE 1:

COMPUTED TRIPPING TIMES (IN SECONDS) FROM RELAY CHARACTERISTICS PROVIDE BY THE MANUFACTURER

\begin{tabular}{|c|c|c|c|c|c|c|c|c|c|c|c|c|c|}
\hline \multirow{2}{*}{\multicolumn{2}{|c|}{ Distortion Level }} & \multicolumn{4}{|c|}{ Standard Inverse Characteristic } & \multicolumn{4}{|c|}{ Very Inverse Characteristic } & \multicolumn{4}{|c|}{ Extremely Inverse Characteristic } \\
\hline & & \multirow{2}{*}{$\begin{array}{c}\text { Fun } \\
38.32 \\
39.35 \\
29.17\end{array}$} & \multirow{2}{*}{$\begin{array}{c}\text { THD I }_{\text {I }} \\
=\mathbf{1 0 \%}\end{array}$} & \multirow{2}{*}{$\begin{array}{r}\begin{array}{r}\text { THD } \\
\text { =20\% }\end{array} \\
34.39 \\
35.87 \\
19.03\end{array}$} & \multirow{2}{*}{$\begin{array}{l}\begin{array}{l}\text { THD } \\
=30 \%\end{array} \\
30.64 \\
32.17 \\
16.97\end{array}$} & \multirow{2}{*}{$\begin{array}{c}\text { Fun } \\
67.50 \\
68.88 \\
49.06\end{array}$} & \multirow{2}{*}{$\begin{array}{l}\begin{array}{c}\text { THD }_{\text {I }} \\
=10 \%\end{array} \\
65.42 \\
67.09 \\
36.81\end{array}$} & \multirow{2}{*}{$\begin{array}{c}\begin{array}{c}\text { THD }_{\text {I }} \\
=\mathbf{2 0 \%}\end{array} \\
59.94 \\
61.88 \\
29.80\end{array}$} & \multirow{2}{*}{$\begin{array}{c}\begin{array}{c}\text { THD }_{\mathbf{I}} \\
=\mathbf{3 0 \%}\end{array} \\
52.73 \\
54.71 \\
25.88\end{array}$} & \multirow{2}{*}{$\begin{array}{c}\text { Fun } \\
181.82 \\
183.86 \\
125.84\end{array}$} & \multirow{2}{*}{$\begin{array}{c}\text { THD }_{\text {I }} \\
=10 \%\end{array}$} & \multirow{2}{*}{$\begin{array}{c}\text { THD }_{\text {I }} \\
=20 \%\end{array}$} & \multirow{2}{*}{$\begin{array}{c}\mathbf{T H D}_{\mathbf{I}} \\
=\mathbf{3 0 \%}\end{array}$} \\
\hline $\begin{array}{l}1 \\
2 \\
3\end{array}$ & $\begin{array}{l}1.2\left(\mathbf{I}_{\text {pickup }}\right)^{*} \\
1.2\left(\mathbf{I}_{\text {pickup }}\right)^{* *} \\
1.2\left(\mathbf{I}_{\text {pickup }}\right)^{* * *}\end{array}$ & & & & & & & & & & & & \\
\hline $\begin{array}{l}4 \\
5 \\
6\end{array}$ & $\begin{array}{l}\left.\text { 1.6(I } \mathbf{I}_{\text {pickup }}\right)^{*} \\
1.6\left(\mathbf{I}_{\text {pickup }}\right)^{* *} \\
1.6\left(\mathbf{I}_{\text {pickup }}\right)^{* * *}\end{array}$ & $\begin{array}{l}14.82 \\
15.13 \\
14.22\end{array}$ & $\begin{array}{l}14.66 \\
15.02 \\
12.52\end{array}$ & $\begin{array}{l}14.19 \\
14.57 \\
11.18\end{array}$ & $\begin{array}{l}13.51 \\
13.90 \\
10.15\end{array}$ & $\begin{array}{l}22.50 \\
22.78 \\
20.78\end{array}$ & $\begin{array}{l}22.19 \\
22.50 \\
17.89\end{array}$ & $\begin{array}{l}21.31 \\
21.70 \\
15.41\end{array}$ & $\begin{array}{l}20.01 \\
20.45 \\
13.61\end{array}$ & $\begin{array}{l}51.28 \\
52.02 \\
47.33\end{array}$ & $\begin{array}{l}50.40 \\
51.12 \\
38.01\end{array}$ & $\begin{array}{l}47.94 \\
48.88 \\
31.74\end{array}$ & $\begin{array}{l}44.33 \\
45.29 \\
26.96\end{array}$ \\
\hline $\begin{array}{l}7 \\
8 \\
9\end{array}$ & $\begin{array}{l}2\left(\mathbf{I}_{\text {pickup }}\right)^{* *} \\
2\left(\mathbf{I}_{\text {pickup }}\right)^{* *} \\
2\left(\mathbf{I}_{\text {pickup }}\right)^{* * *}\end{array}$ & $\begin{array}{l}10.03 \\
10.20 \\
10.20\end{array}$ & $\begin{array}{c}9.95 \\
10.13 \\
9.02\end{array}$ & $\begin{array}{l}9.73 \\
9.98 \\
8.60\end{array}$ & $\begin{array}{l}9.41 \\
9.64 \\
8.11\end{array}$ & $\begin{array}{l}13.50 \\
13.81 \\
13.51\end{array}$ & $\begin{array}{l}13.36 \\
13.69 \\
11.83\end{array}$ & $\begin{array}{l}12.96 \\
13.27 \\
10.83\end{array}$ & $\begin{array}{c}12.35 \\
12.74 \\
9.93\end{array}$ & $\begin{array}{l}26.67 \\
27.35 \\
26.65\end{array}$ & $\begin{array}{l}26.29 \\
26.91 \\
21.98\end{array}$ & $\begin{array}{l}25.24 \\
26.01 \\
18.96\end{array}$ & $\begin{array}{l}23.65 \\
24.30 \\
15.29\end{array}$ \\
\hline $\begin{array}{l}10 \\
11 \\
12\end{array}$ & $\begin{array}{l}2.4\left(\mathbf{I}_{\text {pickup }}\right)^{*} \\
2.4\left(\mathbf{I}_{\text {pickup }}\right)^{* *} \\
2.4\left(\mathbf{I}_{\text {pickup }}\right)^{* * *}\end{array}$ & $\begin{array}{l}7.93 \\
7.99 \\
8.48 \\
\end{array}$ & $\begin{array}{l}7.88 \\
7.96 \\
7.95 \\
\end{array}$ & $\begin{array}{l}7.74 \\
7.86 \\
7.68\end{array}$ & $\begin{array}{l}7.53 \\
7.64 \\
7.48\end{array}$ & $\begin{array}{c}9.64 \\
9.73 \\
10.63\end{array}$ & $\begin{array}{l}9.56 \\
9.67 \\
9.67\end{array}$ & $\begin{array}{l}9.31 \\
9.42 \\
9.15\end{array}$ & $\begin{array}{l}8.93 \\
9.07 \\
8.78\end{array}$ & $\begin{array}{l}16.81 \\
16.93 \\
19.00\end{array}$ & $\begin{array}{l}16.59 \\
16.70 \\
16.81\end{array}$ & $\begin{array}{l}15.99 \\
16.14 \\
15.20\end{array}$ & $\begin{array}{l}15.07 \\
15.25 \\
14.20\end{array}$ \\
\hline $\begin{array}{l}13 \\
14 \\
15\end{array}$ & $\begin{array}{l}2.8\left(\mathbf{I}_{\text {pickup }}\right)^{*} \\
2.8\left(\mathbf{I}_{\text {pickup }}\right)^{* *} \\
2.8\left(\mathbf{I}_{\text {pickup }}\right)^{* * *}\end{array}$ & $\begin{array}{l}6.73 \\
6.78 \\
7.24\end{array}$ & $\begin{array}{l}6.69 \\
6.75 \\
6.77\end{array}$ & $\begin{array}{l}6.59 \\
6.67 \\
6.42\end{array}$ & $\begin{array}{l}6.44 \\
6.54 \\
6.29\end{array}$ & $\begin{array}{l}7.50 \\
7.57 \\
8.44\end{array}$ & $\begin{array}{l}7.44 \\
7.53 \\
7.52\end{array}$ & $\begin{array}{l}7.26 \\
7.38 \\
6.92\end{array}$ & $\begin{array}{l}6.99 \\
7.09 \\
6.75\end{array}$ & $\begin{array}{l}11.70 \\
11.77 \\
13.60\end{array}$ & $\begin{array}{l}11.56 \\
11.66 \\
11.73\end{array}$ & $\begin{array}{l}11.15 \\
11.27 \\
10.22\end{array}$ & $\begin{array}{c}10.54 \\
10.71 \\
9.67\end{array}$ \\
\hline $\begin{array}{l}16 \\
17 \\
18\end{array}$ & $\begin{array}{l}3.2\left(\mathbf{I}_{\text {pickup }}\right)^{*} \\
3.2\left(\mathbf{I}_{\text {pickup }}\right)^{* *} \\
3.2\left(\mathbf{I}_{\text {pickup }}\right)^{* * *}\end{array}$ & $\begin{array}{l}5.95 \\
6.00 \\
6.29 \\
\end{array}$ & $\begin{array}{l}5.92 \\
5.97 \\
5.95\end{array}$ & $\begin{array}{l}5.84 \\
5.92 \\
5.64\end{array}$ & $\begin{array}{l}5.72 \\
5.81 \\
5.48\end{array}$ & $\begin{array}{l}6.14 \\
6.22 \\
6.70\end{array}$ & $\begin{array}{l}6.09 \\
6.15 \\
6.11\end{array}$ & $\begin{array}{l}5.95 \\
6.03 \\
5.58\end{array}$ & $\begin{array}{l}5.75 \\
5.84 \\
5.32\end{array}$ & $\begin{array}{l}8.66 \\
8.74 \\
9.76\end{array}$ & $\begin{array}{l}8.56 \\
8.63 \\
8.55\end{array}$ & $\begin{array}{l}8.27 \\
8.41 \\
7.38\end{array}$ & $\begin{array}{l}7.83 \\
7.96 \\
6.84\end{array}$ \\
\hline $\begin{array}{l}19 \\
20 \\
21\end{array}$ & $\begin{array}{l}\left.\text { 3.6(I } \text { I }_{\text {pickup }}\right)^{*} \\
\left.\text { 3.6(I } \text { I }_{\text {pickup }}\right)^{* *} \\
\left.\text { 3.6(I } \text { I }_{\text {pickup }}\right)^{* * *}\end{array}$ & $\begin{array}{l}5.40 \\
5.43 \\
5.68\end{array}$ & $\begin{array}{l}5.37 \\
5.40 \\
5.41\end{array}$ & $\begin{array}{l}5.31 \\
5.38 \\
5.14\end{array}$ & $\begin{array}{l}5.21 \\
5.27 \\
4.98\end{array}$ & $\begin{array}{l}5.19 \\
5.24 \\
5.74\end{array}$ & $\begin{array}{l}5.15 \\
5.21 \\
5.19\end{array}$ & $\begin{array}{l}5.05 \\
5.12 \\
4.76\end{array}$ & $\begin{array}{l}4.88 \\
4.96 \\
4.54\end{array}$ & $\begin{array}{l}6.69 \\
6.78 \\
7.57\end{array}$ & $\begin{array}{l}6.61 \\
6.73 \\
6.66\end{array}$ & $\begin{array}{l}6.39 \\
6.50 \\
5.80\end{array}$ & $\begin{array}{l}6.06 \\
6.17 \\
5.28\end{array}$ \\
\hline $\begin{array}{l}22 \\
23 \\
24\end{array}$ & $\begin{array}{l}\mathbf{4}\left(\mathbf{I}_{\text {pickup }}\right)^{*} \\
\mathbf{4}\left(\mathbf{I}_{\text {pickup }}\right)^{* *} \\
\mathbf{4}\left(\mathbf{I}_{\text {pickup }}\right)^{* * *}\end{array}$ & $\begin{array}{l}4.98 \\
5.03 \\
5.30\end{array}$ & $\begin{array}{l}4.96 \\
5.00 \\
5.07\end{array}$ & $\begin{array}{l}4.91 \\
4.98 \\
4.84\end{array}$ & $\begin{array}{l}4.82 \\
4.90 \\
4.76\end{array}$ & $\begin{array}{l}4.50 \\
4.55 \\
5.01\end{array}$ & $\begin{array}{l}4.47 \\
4.52 \\
4.56\end{array}$ & $\begin{array}{l}4.38 \\
4.46 \\
4.27\end{array}$ & $\begin{array}{l}4.24 \\
4.30 \\
4.18\end{array}$ & $\begin{array}{l}5.33 \\
5.44 \\
6.48 \\
\end{array}$ & $\begin{array}{l}5.27 \\
5.38 \\
5.53\end{array}$ & $\begin{array}{l}5.10 \\
5.21 \\
4.86\end{array}$ & $\begin{array}{l}4.84 \\
4.93 \\
4.59\end{array}$ \\
\hline $\begin{array}{l}25 \\
26 \\
27\end{array}$ & $\begin{array}{l}\text { 4.4( }\left(I_{\text {pickup }}\right)^{*} \\
\operatorname{4.4}^{*}\left(I_{\text {pickup }}\right)^{* *} \\
\operatorname{4.4}_{\left(I_{\text {pickup }}\right)^{* * *}}\end{array}$ & $\begin{array}{l}4.65 \\
4.71 \\
4.90\end{array}$ & $\begin{array}{l}4.64 \\
4.68 \\
4.70\end{array}$ & $\begin{array}{l}4.59 \\
4.65 \\
4.52\end{array}$ & $\begin{array}{l}4.51 \\
4.57 \\
4.41\end{array}$ & $\begin{array}{l}3.97 \\
4.02 \\
4.36\end{array}$ & $\begin{array}{l}3.94 \\
4.02 \\
4.06\end{array}$ & $\begin{array}{l}3.87 \\
3.92 \\
3.75\end{array}$ & $\begin{array}{l}3.74 \\
3.83 \\
3.49\end{array}$ & $\begin{array}{l}4.36 \\
4.43 \\
5.02\end{array}$ & $\begin{array}{l}4.31 \\
4.37 \\
4.51\end{array}$ & $\begin{array}{l}4.17 \\
4.26 \\
3.93\end{array}$ & $\begin{array}{l}3.96 \\
4.04 \\
3.60\end{array}$ \\
\hline
\end{tabular}

*) tripping times from relay characteristics, 


\section{CONCLUSIONS}

Theoretical and experimental analyses of this paper have shown the influence of harmonic on solid state overcurrent relays. A representative relay was tested using sinusoidal and distorted currents containing low order harmonics. Main conclusions are:

- Waveform distortion does affect the performance of protective relays and may cause them to operate improperly. In most cases, the waveform distortion of the load current has little effect on the fault current. However, for overloaded conditions (or for low magnitude faults) the current may contain substantial harmonics and distortion can become a significant factor.

- Based on test results, it can be generally concluded that the effect of harmonic currents would lead to a shortened operation time of the solid-state relays; and relay performs differently when $\mathrm{THD}_{\mathrm{I}}$ waveform distortion varies. Moreover, relay may even respond differently when different characteristics are investigated.

- The higher the $\mathrm{THD}_{\mathrm{I}}$, the greater the variation of tripping time that can be seen. Significant deviations can occur with $20 \%$ or greater THD in current waveform at all three (Standard Inverse, Very Inverse and Extremely Inverse) characteristics of relay.

- Harmonics mostly show significant effects on tripping time at overload current ranges (1.2 to 2 times of pickup current); in case of fault conditions, those effects are theoretically negligible. As the magnitude of the fundamental current increases the relative impact of harmonic current on relay tripping in reduced.

- Finally, it is likely to be impossible to generalize the behavior of any relay response to harmonics without actual tests, as the actual test results show larger deviations than that of theoretical calculation and software simulation.

\section{REFERENCES}

[1] Kazibwe, W.E.; Ringlee, R.J.; Woodzell, G.W.; Sendaula, H.M.; "Power quality: a review", Computer Applications in Power, IEEE, Volume 3, Issue 1, Jan. 1990, Page(s):39-42.

[2] Masoum, M.A.S.; Fuchs, E.F.; Roesler, D.; "Impact of Nonlinear Loads on Anisotropic Transformers", IEEE Trans. on Power Delivery, Vol.6, No.4, Oct. 1991, Page(s): 17811788.

[3] Wagner, V.E.; Balda, J.C.; Griffith, D.C.; McEachern, A.; Barnes, T.M.; Hartmann, D.P.; Phileggi, D.J.; Emannuel, A.E.; Horton, W.F.; Reid, W.E.; Ferraro, R.J.; Jewell, W.T. 'Effects of harmonics on equipment', IEEE Transactions Power Delivery, Volume. 8, Issue 2, April 1993, Page(s): 672-680.

[4] Stones, J.; Collinson, A.; "Power quality", Power Engineering Journal, Volume 15, Issue 2, April 2001, Page(s):58-64.

[5] Khan, A.K.; "Monitoring power for the future", Power Engineering Journal, Volume 15, Issue 2, April 2001, Page(s): 81-85.

[6] Heydt, G.T.; "Power quality engineering", Power Engineering Review, IEEE, Volume 21, Issue 9, Sept. 2001, Page(s): 5-7.
[7] Mack Grady, W.; Santoso, S.; "Understanding power system harmonics", Power Engineering Review, IEEE, Volume 21, Issue 11, Nov. 2001, Page(s): 8-11.

[8] E.F. Fuchs, D. Roesler, M.A.S. Masoum, "Are Harmonic Recommendations According to IEEE and IEC Too Restrictive?", IEEE Trans. on Power Delivery, Volume19, No.4, Oct 2004, Page(s): 1775-1786.

[9] Herath, H.M.S.C.; Gosbell, V.J.; Perera, S.; "Power quality (PQ) survey reporting: discrete disturbance limits", IEEE Transactions on Power Delivery, Volume 20, Issue 2, Part 1, April 2005, Page(s): 851-858.

[10] Fuller, J.F.; Fuchs, E.F.; Roesler, D.J., 'Influence of harmonics on power distribution system protection', Power Delivery, IEEE Transactions, Volume 3, Issue 2, April 1988, pages 549-557.

[11] Girgis, A.A.; Nims, J.W.; Jacomino, J.; Dalton, J.G.; Bishop, A. 'Effect of voltage harmonics on the operation of solid-state relays in industrial applications', Industry Applications, IEEE Transactions, Volume 28, No. 5, 1992, pages $1166-1173$.

[12] Rob, R.A.; Jewell, W.T., 'Computer based harmonic simulation and testing for microprocessor-based phase distance relay with phase locator', Industrial and Commercial Power Systems Technical Conference, May 1993, pages 7077.

[13] Elmore, W.A.; Kramer, C.A.; Zocholl, S.E., 'Effect of waveform distortion on protective relays' Industry Applications, IEEE Transactions, Volume 29, Issue 2, MarchApril 1993, pages 404-411.

[14] Alstom T\&D Protection \& Control Ltd 1999, Overcurrent relay for phase and earth faults type 22, 42, 52, 53, 62, 63 and 82. Manual Guide.

[15] Manitoba HVDC Research Centre Inc 2003, PSCAD power systems computer aided design. User's Guide.

[16] DaqGen Features. Retrieved September 15, 2005, from http://www.daqarta.com/DGINTRO.HTM. 